\title{
Archival Encounters
}

\section{Rethinking access and care in digital colonial archives}

Agostinho, Daniela

Published in:

Archival Science

DOI:

10.1007/s10502-019-09312-0

Publication date:

2019

Document version

Peer reviewed version

Citation for published version (APA):

Agostinho, D. (2019). Archival Encounters: Rethinking access and care in digital colonial archives. Archival Science, 19(2), 141-165. https://doi.org/10.1007/s10502-019-09312-0 


\title{
Archival encounters: rethinking access and care in digital colonial archives
}

\section{Daniela Agostinho}

\begin{abstract}
The year of 2017 marked the centennial of Denmark's sale of the former Danish West Indies to the United States of America, today the US Virgin Islands (USVI). The colonial archives fgured prominently during the year-long commemorations in Denmark, as the Danish National Archives digitized and publicly released the colonial records of the islands of St. Croix, St. Thomas and St. John. Drawing on cultural theories as well as debates in archival science, this article proposes the notion of 'archival encounter' to centre the ethical-epistemological challenges of digitization and to emphasize the intersected problematics raised by the encounter between the colonial, the archival and the digital. The article begins by revisiting the history of these archives in order to situate the digitization of these records within debates on provenance, custody and access. It then introduces some of the debates taking place within the feld of Atlantic slavery, as well as feminist and critical race theories, to argue that the digitization of the USVI records recasts questions about the limitations and possibilities of colonial archives. Furthermore, the article contends that digitality and datafcation are indebted to colonial histories of quantifcation that structure the technological encounter with the colonial archive. Finally, the article builds on these theorizations to amplify recent calls for a feminist ethics of care in archival praxis. Drawing on postcolonial critiques, the article problematizes and situates the notion of care within the colonial and non-innocent histories in which it is embedded, in order to align ethics of care with a critical reorientation of digital colonial archives. Marshalling a postcolonial feminist critique of care as a framework for thinking, the article suggests, can help us to realign archival encounters in ways that that more pointedly confront the colonial legacies of our present.
\end{abstract}




\section{Keywords}

Colonial archives · United States Virgin Islands · Denmark · Digitization · Access ·

Postcolonial ethics of care

The year 2017 marked the 100th anniversary of Denmark's sale to the United States of the former colonial territories of the Danish West Indies, today known as the United States Virgin Islands (USVI). The archives documenting Danish colonial rule figured prominently in the year-long commemorations in Denmark, as the Danish National Archives released digitized records from the islands of St Croix, St Thomas and St John on their website 'The Danish West Indies - Sources of History'. Five million pages from the local and central administration of the Danish West Indies were digitized between 2013 and 2017, amounting to more than 1.2 kilometres of shelf space. The now digitized collection was included on Unesco's World Heritage List in 1997, and is considered to be one of the best preserved in the world. The digitization and provision of digital access to these records can be seen as the latest instalment in a long and complex historical process that has become a case study in archival science (Bastian 2003). After the sale of the islands, the archival records were split between Denmark, the US and the USVI, raising debates over foundational concepts in the field of archival science such as provenance and custody, and complicating claims over ownership and access. With the removal of a substantial number of records from the islands, Virgin Islanders were left without approximately 250 years of written history. The digitization project thus offered the promise of greater access to these historical records, particularly for the descendants of the documented communities, along with the virtual reunification of scattered materials, and more widespread knowledge of a colonial past that continues to be only residually known and debated. To date the physical archives remain in Denmark.

Throughout the centennial, a plethora of research, discursive, artistic and curatorial interventions - by academic and cultural heritage institutions, researchers, curators, artists and activist groups - foregrounded and debated the structures and possibilities of digital archives, advancing important discussions and methodologies to deal with colonial records. The events and interventions in Denmark during the centennial included, amongst others, the exhibition 'Blind spots', curated by Mathias Danbolt, Mette Kia Krabbe Meyer and Sarah Giersing at the Royal Danish Library, which featured different artefacts from the library's 
collection (photographs maps and postcards, among others) alongside artworks by contemporary artists such as La Vaughn Belle (USVI), Jeannette Ehlers (Denmark) and Nanna Debois Buhl (Denmark); art historian Temi Odumosu's sound interventions, titled 'What lies unspoken', at both the 'Blind spots' exhibition and the National Gallery of Denmark; the conference 'Unfinished histories: Art, memory, and the visual politics of coloniality', organized by Mathias Danbolt and Mette Kia Krabbe Meyer at the University of Copenhagen and the Royal Danish Library; and Jeannette Ehlers and La Vaughn Belle's 'I am Queen Mary', an artist-led monumental statue of labor revolt leader Mary Thomas - the first public monument to a black woman in Denmark - situated in front of the former West Indian Warehouse, which today houses the National Gallery's plaster collection. Other independent and smaller scale events, projects and interventions, organized by artist and activist collectives such as Marronage, Black Lives Matter Denmark and Hvid[mə] Archive, were also crucial in mobilizing local communities around Denmark's colonial legacy, and in leading some of the most radically anti-colonial conversations and experiments. In the USVI there were several artistic and curatorial responses to the centennial, including a group exhibition titled ' 100 years of...: A centennial transfer reflection exhibition' held at the Bajo el Sol Gallery in St John; another group exhibition, titled 'Invisible heritage: transfer 2017', curated by Monica Marin at the Caribbean Museum Center for the Arts in St Croix, which later travelled to the USVI Cultural Embassy in Copenhagen; and the exhibition 'The centennial: my take/my view', shown at the Fort Frederik Museum in St Croix. In general, the centennial commemorations fostered only a few transatlantic initiatives, mostly spearheaded by individual artists, curators and researchers outside the framework of official commemorations.

These activities make up the larger cultural context within which the digitized records were released. While the digitization and digital access to the archives played a central role in inscribing the memory of Danish colonialism into public debates (at least during the centennial year, alongside all the above-mentioned activities), it also showed that the digitization of contested archival material is never a merely technical process, entangled as it is with power differentials, racial and national imaginaries, memory politics and colonial legacies that continue to shape the societies whose histories are connected and disconnected by colonial archives (Dirckinck-Holmfeld et al. 2019). 
Danish colonialism continues to occupy a marginal position in public narratives of the history of Denmark. Not unlike other European nations, Denmark's relationship to its colonial past is predominantly characterized by a refusal to see itself as a colonial power. On the occasions when Denmark does acknowledge its colonial past, it does so through a narrative of 'colonial innocence' (Andersen 2014) and benevolent exceptionalism, removed from the violence of Danish involvement in the transatlantic slave trade and the plantation economy (Andersen 2014; Jensen 2018; Körber 2018). This self-perception has been put to the test by claims for reparations made by Virgin Islanders since 1998, as well as by several demands for a public apology for the Danish involvement in slavery, the slave trade, and the sale of the territory to the US in 1917 (Andersen 2018). Yet these demands have been consistently rebuffed by Danish governments. A recurring reason invoked by Danish politicians to refuse to issue a public apology is the idea that Denmark today cannot be held accountable for injustices committed in the past. This disavowal of transgenerational moral commitments strongly contrasts with practices that have come to play a significant role in global politics, expressed in the form of commemorations, statements of regret, restitution, amends, and other modes of compensation and responsibilization for historical injustices and atrocities. The disavowal is all the more troublesome as Denmark did issue a public apology to the Inughuits of northern Greenland - one year after the demands were made by the USVI - and has also apologized for turning away Jewish refugees at Danish borders between 1933 and 1940 (Andersen 2014, pp 12-13). These instances testify to the marginal position that colonialism in Africa and the Caribbean occupies in public narratives of Denmark's history, whereby the significance of these colonial experiences is continuously belittled. This marginality is further reinforced by a commitment to bilateral US-Danish relations. Given that the USVI are still a colony of the US (classified by the United Nations as a 'non-self-governing territory'), a Danish apology to the USVI would necessarily involve the US, a country where the ongoing question of reparations for slavery continues to be debated (Araújo 2017). In 2008, the US Congress adopted a resolution apologizing for slavery and Jim Crow legislation - an apology that was severely criticized for its circumspection, and for not being followed up with reparations (or at least a debate) of any kind.

Denmark's refusal to be held accountable for its colonial past was once again reiterated during the centennial in 2017, this time with some developments in language that indicated new layers of colonial innocence. Danish politicians on different occasions during 
the centennial referred to slavery as 'unforgivable', an expression that allowed them to express regret while eschewing accountability (Körber 2018, p 25). Colonialism and slavery were also described as 'shameful', gesturing towards an affective dimension centred on national feelings (rather than on the affected communities who were demanding an apology) that did not translate into accountability for past deeds. To echo Lill-Ann Körber's argument, these public feelings testify to a particular 'Danish economy of guilt' that brings together two facets: on the one hand, a reluctance to acknowledge accountability and guilt, anchored in the idea of innocent colonialism or 'white innocence' (Wekker 2016); and on the other, a privileged position in the global capitalist world order, acquired through that very colonialism and translated into a sense of entitlement. This colonial entitlement materializes in the privilege to decide whether to apologize or not, whether past deeds inflicted pain or not, and whether the violence of the past is relevant to the present of Denmark (Körber 2018, p. 27). As Tami Navarro argues, while Denmark debates it's self-proclaimed "forgotten history", this history has continued to shape the lived experiences of Virgin Islanders (Navarro, 2017). Ultimately, what these affective modalities show is that the centennial commemorations centred on Danish perspectives on colonial history, and on Denmark's coming to terms with its own image. As Danbolt and Wilson (2018) argue, 'if the Centennial marked a shift in Denmark's relationship to its colonial past, it marked a willingness to discuss the depths of Denmark's relationship with itself, more than its relationship with its former colony'.

The digitization of the colonial archives of the USVI has to be situated and understood within this historical, political and affective context. Announced as one of the main initiatives of the commemorations, the release of the digitized archives was presented as a promise of more knowledge about Denmark's colonial history, a gesture that could fit all too neatly into the narrative of admitting the 'shameful' and 'unforgivable' nature of colonialism and slavery without any consequent acts of transgenerational accountability. The question, then, is how the digitization and release of the colonial archives can advance collective knowledge in ways that help us move beyond national economies of guilt and innocence, towards a consequent confrontation of colonial legacies that continue to structure the present.

This question repurposes a familiar problematic in archival science and postcolonial studies: while colonial archives are always beset by colonial politics, knowledge gaps and traces of violence, they can also represent an opportunity to confront colonial dynamics, to 
challenge narratives of colonial innocence, and to complement the absences and silences of the archive with materials and narratives that reflect the experiences of documented communities (Risam 2018, p 47). But one should add that in this case, given Denmark's reiterations of colonial innocence, the opening up of the archives constitutes an opportunity not only to generate new knowledge, but also to confront the "politics of our lack of knowledge' (Lowe 2015, p 39). As Lisa Lowe forcefully argues, the 'forgetting of the violent encounter' of colonialism is naturalized both by the archive itself and in subsequent narrative histories (2015, pp 2-3). In other words, narratives of colonial innocence and benevolent exceptionalism, so prevalent in Danish public discourses, are often enabled by the logics of colonial archives, which tend to subsume the violence of the colonial experience within narratives of state reason and progress. This raises the stakes of the digitization of colonial archives, and posits a constellation of political, epistemological and ethical challenges that need to be addressed. What kind of knowledge, and whose knowledge, can be generated by digitization and open access to these archives? And how can digitization and access pave the way to confronting and redressing the violence of colonialism, rather than reinstating innocent histories?

Disciplinarily and methodologically, the digitization of the archives also demonstrated that a continued and mutually informing dialogue between archival science and the (digital) humanities is of critical importance to advance conversations about contested colonial archives and the development of decolonial archival ideas and practices. Drawing on cultural theories as well as debates in archival science, and responding to calls for interdisciplinary exchange between these fields (Caswell 2016; Caswell et al. 2017), this article wishes to contribute to this much-needed dialogue by centring the ethical-epistemological challenges and political stakes raised by the digitization of the colonial archives of the USVI. The article proposes the notion of 'archival encounter' to emphasize the intersected problematics raised by the encounter between the colonial, the archival and the digital. Expanding on Lisa Lowe (2015), this notion of encounter seeks on the one hand to draw attention to the role of digitization in potentially unearthing the violent encounter of colonialism, and on the other hand to foreground the ethics and responsibility involved in encountering materials that are antithetical to black life, materials that carry persistent power differentials and unresolved political demands that need to be heard. In essence, the article asks how the digital encounter 
with these archives can be meaningfully mobilized in favour of archival engagements committed to recognizing and redressing historical injustices.

The article begins by revisiting the history of these archives, drawing on and expanding Jeannette A. Bastian's groundbreaking research, in order to situate the digitization of these archival records within debates on provenance, custody and access. It then introduces some of the debates taking place within archive theories in the field of Atlantic slavery, as well as feminist and critical race theories, to demonstrate how the digitization of the USVI records recasts questions about the limitations and possibilities of colonial archives. More specifically, it argues that the provision of access is embedded in modern racializing processes that demarcate who counts as a human subject worthy of rights and who is excluded from personhood. Furthermore, the article contends that digitality and datafication are also indebted to colonial histories of quantification that structure the technological encounter with the colonial archive. Finally, the article builds on these theorizations to amplify recent calls for a feminist ethics of care in archival praxis. Drawing on postcolonial critiques, the article contributes to this debate by problematizing and situating the notion of care within the colonial and 'non-innocent histories' (Murphy 2015) in which it is embedded, in order to mobilize an ethics of care towards a critical reorientation of digital colonial archives. Marshalling a postcolonial feminist critique of care as a framework for thinking, I suggest, can help us to realign archival encounters in ways that open up political possibilities that more pointedly confront the colonial legacies of our present.

\section{The colonial archives of the USVI: a case of archival dispossession}

The somewhat sinuous process that led to the removal of records from the USVI forms the historical background for the digitization project that culminated during the centennial in 2017, and is therefore worth briefly recalling. The historical background that I retrace here relies heavily on Jeannette Bastian's research $(2001$; 2002; 2003), which is based on her PhD thesis (Bastian 1999). Bastian was Territorial Librarian of the USVI from 1987 to 1998, and her work still constitutes an international reference in this case. After 1917, when the US purchased the Danish West Indies from Denmark, Danish archivists removed the majority of the records that had been created on the islands during Denmark's colonial rule, and deposited them in the Danish National Archives in Copenhagen. Later, following their establishment in the 1930s, the US National Archives claimed most of the remaining records 
and shipped them to Washington, DC. Such custody claims not only caused fragmentation of the records, but were also made without consulting - and sometimes against the resistance of - the islands' inhabitants, whose history is documented in those records.

Danish imperial history can be traced back to early explorations of the North Atlantic in search of the Northwest Passage in the fifteenth century. According to Lars Jensen (2018), these sporadic explorations can be seen as precursors to the launch of Danish colonialism with the large expedition sent by King Christian IV in 1618 to secure a monopoly on trade with Ceylon (Sri Lanka). While the expedition failed to achieve its goal, it paved the way for the establishment of a fortified trading post on the east coast of India at Tharangambadi (Tranquebar), south of Puducherry (Pondicherry), in 1620. A colony was established on the Gold Coast (Ghana) in 1658 to secure Danish participation in the slave trade, while colonization of the Danish West Indies began in 1665. The colonies here were established as plantation societies based on enslaved labour (Jensen 2018).

Early settlement in St Thomas was sponsored by the Danish West India Company, a commercial venture chartered by the Danish Crown to develop trading areas for Denmark in the West Indies. In 1674, the King of Denmark granted the Danish West India Company a royal charter to assume control of the Guinea Company, a slave trade operation created in 1672 and located on the West African coast. The need for labour on the plantations of St Thomas led to massive involvement in the transatlantic slave trade, so much so that by 1715 the white population of St Thomas was only 547, while the enslaved population numbered 3042 distributed over 160 plantations (Bastian 2001, p 99). In spite of the profitability of the slave trade, the Danish West India Company incurred major losses due to the costs of colonization, the debts incurred by planters and underwritten by the Company, and losses of slave ships. With a view to making a profit, Danes settled the island of St John in 1718 and purchased St Croix from France in 1733. Because the Company was still unable to make a profit, in 1752 the Danish Crown dissolved the Danish West India and Guinea Company and took over administration of the islands.

Due to this early period of administration of the island by the Danish West India Company, the West Indian local archives are traditionally placed together with the audited West Indian and Guinean accounts. In terms of provenance, this large group of West Indian accounts actually belongs with other audited accounts, but it is nevertheless treated together with the West Indian local archives. Altogether the extant West Indian local archives kept at 
the Danish National Archives in Copenhagen take up c. 800 running metres or 9,647 boxes and bound volumes, while the audited West Indian accounts take up another c. 150 running metres or 2,099 boxes and volumes, while the Guinean audited accounts take up c. 8 running metres or 77 boxes and volumes. Since the official language of the colonies was Danish, all official records were produced in this language, even though it was not the lingua franca of the majority of the population. Danish was not taught to the population, and it was only in the 1860s that official public documents were published in both English and Danish. Even court testimony given in English (or any other language) was transcribed and then translated into Danish.

This early administration by the Danish West India Company is clearly indicative of the capitalist extraction that drove and structured colonial settlement on the islands. The capitalist history that underwrote the colonization of the islands is evident in the organization of the archives, where records that document slave trade transactions exist alongside documents of colonial governmentality: censuses, pay books, ships' logs, ledgers, cargo books, trade journals, diaries, auction books, lists of bonds, debt lists, loans for the acquisition of slaves, insurance policies, distillery and plantation books, reckonings of slaves sold, reports on the work of field and skilled slaves, compensation paid to slaveholders after emancipation, and police and hospital records. Such records document the centrality of the capitalist venture and its intersection with colonial modes of governmentality.

By the mid-nineteenth century, colonial officials in the Danish West Indies, as well as officials in Denmark, began to express concerns about the maintenance of local government records due to the tropical weather, the often poor storage conditions, and the uncertain political climate generated by contestations and recurring rebellions throughout the colonized territories. A hurricane in 1772 had destroyed many of the pre-1755 records, and during the 1848 emancipation rebellion on St Croix, all the court and criminal records in Frederiksted police station were destroyed (Bastian 2001, p 102). As a result of these conditions and incidents, the Danish government determined that pre-1840 records should be transferred from the islands to Copenhagen, on the grounds that these records could be considered purely historical, as they were deemed no longer useful or necessary to administer the islands. After the sale of the islands in 1917, a large final shipment of records was made in 1921. In addition to these, the records of the Danish West India Company had already been shipped to 
the Royal Archive in 1759 upon the dissolution of the Company. After the transfer of the islands to the US, intricate custody claims over the records began to take shape.

As Bastian (2001, p 103) recalls, the 1916 treaty of sale between Denmark and the US specifically stipulated that with the transfer of the islands from Denmark to the US, the archives and records should also be ceded to the new governing power. In her detailed analysis of the case, Bastian argues that the treaty legally entitled the US to the records, but the US paid little or no attention to them in the years following the transfer. Some of the possible reasons for this neglect include the urgency of administering day-to-day life on the islands after the US assumed control, when finances and public health were perceived as far more pressing issues. In addition, the fact that there were no national archives in the US at the time meant that there was no institutional mandate to collect and preserve the records.

Given this disregard, various Danish historical societies began to lobby to bring the records to the Danish National Archives. Arguing for the historical importance of keeping the records, a joint committee formed by different interest groups recommended that the pre-1863 records be taken to Denmark on the grounds that they no longer had administrative relevance, while the remainder should be evaluated by archivists. Agreeing with the recommendation, the Danish government sent archivist Georg Saxild to the islands to negotiate for some of the records to be sent to Denmark. The Danish proposal included taking government archives up to 1900, probate inventories until 1885, and any records of community committees kept in the government archives. The proposal excluded deed and mortgage letter books, which were interpreted as reflecting the rights and property of the inhabitants as stipulated in the treaty (Bastian 2001, p 104). Due to the new administration's scant interest in the records, the negotiations proved to be easy. Saxild's proposal was accepted unconditionally, and over 2000 linear feet of records were transferred to the Danish National Archives. The fact that the records were in Danish must explain, at least in part, the lack of interest expressed by the US.

Yet in 1936 the newly established US National Archives, acknowledging their legal entitlement to and responsibility for the records, sent a Danish-speaking archivist, Harold Larson, to the USVI as part of a survey of federal records. In his assessment, Larson excluded all that had been created after 1917, considering that these records should remain on the islands. His accessions are of records dating from after the initial cut-off date of 1848 set by the Danes - although some, particularly from St Croix, date back to the seventeenth century. 
Significantly for us today, his report suggests that problems for future researchers would include not only the fragile physical condition of the records, but also the facts that they were written in Danish, that the older records used Gothic script, and that the handwriting was often illegible.

In 1942, the US National Archives sent another archivist, Gaston Litton, on a mission to survey the federal records of the USVI, Puerto Rico, Panama and the Canal Zone, to report on their physical condition, and to recommend dispositions and transfers to Washington. The goal was to transfer inactive government records, as well as remaining Danish records, to the safekeeping of the National Archives, since the USVI had neither the facilities nor the staff to take care of them. In spite of resistance from the municipal councils of St Thomas, St John and St Croix, Litton and the government secretary and acting governor of the USVI, Robert Lovett, managed to persuade many of the other local USVI offices to transfer their inactive files. Litton noted particularly that many of the remaining Danish records complemented existing record series held in the US National Archives (Bastian 2001, p 107). Records pertaining to the Danish West Indies/USVI were deposited in a number of record groups in the US National Archives, but the bulk of them are in record group 55.

This sinuous process, which I have only been able to briefly sketch here, testifies to the archival dispossession to which the USVI were subjected both before and after the transfer in 1917. This drainage clearly demonstrates that not only are archives essential instruments of colonial governance (Stoler 2002), but they also remain coveted sites of knowledge - and thus of power - after periods of colonial rule. As Bastian (2002, p 82) exemplarily puts it: 'control of the records means control of the subjects of the records'. Postcolonial custody claims often extend the power dynamics of colonial times, accentuating - often insidiously - unequal power structures. The reasons invoked for custody claims are often imbued with what postcolonial feminist theorists term 'paternalistic care', reminiscent of the sort of care found in colonial discourse that constructs the colonized other as a disempowered subject in need of guidance and protection (Narayan 1995). In the case of the USVI, Denmark recurrently invoked the need to remove and assume custody of the records on the assumption that they could not be taken care of by others, since the islands did not offer the right conditions for their preservation. While the lack of adequate conditions is a consequence of decades of colonial neglect and abandonment, these conditions are repeatedly severed from colonial exploitation and constructed as an essentially native problem. The 
argument for archival care evoked in custody claims makes it extremely difficult to challenge and reclaim ownership of wrongfully removed records, as the benevolence in which it is shrouded effaces, or attempts to minimize, the fundamentally colonial gesture that motivates custodianship. The fact that the records are included on Unesco's World Heritage List and are considered to be among the best preserved in the world can be seen as an example of archival care that complicates discussions about ownership, as it seems to validate the Danish custodial role. It is therefore crucial to problematize and rethink the notions of custody and provenance, and the way they intersect with care, as they lie at the core of the question of what a decolonial archival praxis might look like in the case of the USVI.

\section{Rethinking custody and provenance: on communities of records}

The shared custody of the pre-1917 records between Denmark and the US is informed by specific interpretations of custody and provenance, principles that have been extensively problematized and rethought over the last decades. The notion of custody as physical possession and legal responsibility (Bastian 2001, p 108) finds itself challenged and rendered insufficient by the colonial records of the USVI. After all, the Danish government decided to relocate the records to Denmark on the assumption that the records - created by Danes executing Danish policy in Danish offices in colonial territories that functioned as extensions of Denmark - rightfully belonged to the Danish National Archives. Within this nationalistic interpretation, Danish West Indian colonial records created both in Denmark and on the West Indian islands share the same provenance because the records' creators are equivalent, and they can thus be seen as falling within the same archival fonds. While Denmark has taken physical custody of the records, its claim to legal custody in light of the treaty of sale is ambiguous. To validly claim legal custody following the treaty, Denmark would have had to demonstrate that none of the records concerned the 'property and right' of the inhabitants of the USVI. Throughout the process that drained the USVI of its archives, 'property and right' was narrowly interpreted: the rights of the inhabitants of the USVI were generally not considered, except insofar as property and some legal records remained within the territory.

While it could be argued (within a legalistic framework) that each government made legitimate interpretations of the treaty of sale, the heart of the matter is that the subjects documented by the records and their descendants did not play an active role in the custody claims, and access to the records was rendered extremely difficult for them. In her reading of 
the case, Bastian (2003) notably argues for a reconsideration of custody premised on the provision of access, and for an expansion of the notion of provenance to include the subjects of records and not just their creators. For Bastian, the fact that the inhabitants of the islands whose lives are documented by these records - were not taken into consideration in custody decisions calls into question the validity of the entire custodial role.

Bastian (2003) importantly demonstrates that in the absence of written records, which continue to be kept by former and current colonial powers, the Virgin Islanders have reconstructed their history through oral tradition, folklore and public commemorations (Bastian 2003). Acknowledging that other modes of identity, memory and community-building exist outside and alongside the conventional modes of written history 'the repertoire of embodied memory', as Diana Taylor (2003) terms it - is an essential part of decolonizing knowledge, and of recognizing the active reconstruction of identity by communities that, for various reasons, do not have access to written sources concerning their own history. Yet this should not deter us from reiterating the importance of access to and interpretive power over written archival records as an essential part of the reconstruction of a community's identity. In the case of the USVI, there is often a tension between oral traditions and archival records, rather than a neat complementarity, insofar as the archives and the folklore often tell different stories given that access to the historical records has been rendered difficult if not impossible for Virgin Islanders. As a result of this archival dispossession, the islanders' historical past is often told and interpreted by scholars and researchers from outside the community, and often does not match the collective, unwritten imaginings that constitute a significant part of communal life on the islands.

An example thereof is the Fireburn, a 1878 labor uprising by nominally free black people on St Croix known to have been led by a group of women: 'Queen Mary' Thomas, 'Queen Agnes' Salomon and 'Queen Mathilda' McBean. The three women - symbols of the rebellion on the islands, and known as the three 'rebel queens' - were sentenced to jail, and served their terms in the women's prison in Christianshavn in Copenhagen. In 2004, former Virgin Islands Senator Wayne James located Danish documents that revealed the existence of a fourth 'queen', Susanna Abramsen. The USVI Studies Collective (Tami Navarro, Tiphanie Yanique, LaVaughn Belle and Hadiya Sewer) are currently working on the four queens' prison records, in order to confront and explore the potential gaps between the written documents produced by the Danish administration and the histories captured by Virgin 
Islanders. This possibility of confronting and exploring the gaps between traditions and written documents once again makes clear the stakes involved in creating new knowledge, confronting and shifting power differentials regarding who gets to produce knowledge, and what kind of knowledge. But the fact that these records are written in Danish and the handwriting is not easily readable constitute further obstacles to access that digitization alone does not resolve.

This desire, need and right of communities to reconstruct their histories has led to an increased recognition of access as part of the custodial obligation, as advocated by post-custodial archive theory. Post-custodial thinking acknowledges that collecting and preserving records is no longer enough to fulfil archival obligations. As Bastian (2002, p 91) puts it: "custody only serves an archival purpose in the long term if it accommodates the people and events to whom the records relate as well as the collective memory that the records foster'. Also inherent to this notion is the expansion of provenance and the recognition of the subjects of records as 'stakeholders' who also hold rights to the archived records. Bastian (2003, p 3) famously advocates the inclusion of documented communities within the scope of provenance, proposing the notion of a 'community of records' whereby the 'records of a community become the products of a multitiered process of creation that begins with the individual creator but can be fully realized only within the expanse of this creator's entire society'. The documented communities are thus seen as providing the necessary context for the records, without which their interpretation is incomplete. As Christian Kelleher (2017, p 1) recently formulated it, post-custodial praxis is essential to democratize the power dynamic of archives 'by decoupling the value of archival records from dependence on the archival repository, and prioritizing the context of records creation over records content'. In this way, the entire community becomes the larger provenance of the records, and all layers of society are seen as equal participants in the making and interpretation of records.

While the provision of access is increasingly recognized as a significant, even primary component of the custodial obligation, access remains a contested notion and practice within debates on decolonizing archives and colonial heritage. If there is a consensus that documented communities are entitled to facilitated access to the records containing their histories, that access is often implicated in and conditioned by power differentials that complicate, and may undermine, decolonial aspirations. As postcolonial digital humanities 
have shown, digitization is often secondary to Caribbean sources, as other barriers to access, such as language, continue to prevent a full engagement with the records.

The following sections will discuss how digitization often emerges as a promise to facilitate access but is nevertheless embedded in the power structures that shape colonial archives themselves. Left unattended, these power structures may condition and hinder the potential of post-custodial thinking, that is, a full contribution by documented communities or their descendants to the making and interpretation of records.

\section{On being accessed}

Given the complex history of the archival records in question, it is not hard to imagine how the digitization of the colonial records held by the Danish National Archives came to be presented as an important step in the relationship between Denmark and the USVI. Recognizing access as part of their custodial obligation, the Danish National Archives presented the project as a step towards greater access to the records, and towards widening knowledge about the colonial past. Yet the digital release of the records met with mixed reactions. On the website dedicated to the digitization project, 'The Danish West-Indies: sources of history', the Danish National Archives claim to want 'everyone to have access to the records - including those with family ties to the colony and regardless if they live in the Caribbean, in Denmark or in the U.S.A.' (Rigsarkivet n.d.). Further, the website states that 'history must be told', expressing the hope that the digitization of the records will contribute to more widespread knowledge about Denmark's colonial history. Already here one can anticipate some of the criticisms with which the release of the records was met. Firstly, the decision to make the records accessible to everyone was widely debated, with voices on both sides of the Atlantic raising ethical concerns about open access to highly sensitive material, such as records from slave auctions, reports on the work of enslaved labourers, plantation records that often include descriptions of punishments, and hospital and police reports, not to mention photographic material. In particular, the photographic records, stored in the Royal Danish Library, elicited concerns with regard to the ethics of seeing and showing subjects who had most often been photographed against their will, without an adequate problematization of 'attend[ing] to the dead in the digital commons' (Odumosu 2019).

While the discussion cannot be polarized into two opposing positions, as there were variegated and nuanced viewpoints involved, there was a striking divide between the 
attachment to liberal ideals of open access and the right to information on the one hand, and on the other a concern with the contested nature and affective power of these materials. While for many people such records contain important historical information that needs to be 'mined' and explored for greater knowledge, many others emphasize that these archives solicit a different mode of engagement, one premised on care and redress, insofar as these archives document violence and resistance, and they potentially hold valuable, deeply personal information about ancestors and events. They thus require specific practices of information management that go beyond simple online availability. La Vaughn Belle (2018), a visual artist based in St Croix, has proposed the act of 'unseeing' as a decolonial practice, emphasizing the need to unhinge colonial images from colonial economies of seeing, while art historian Temi Odumosu (2019) draws attention to the formulation and enactment of reparative modes of engagement with contested visual material. Both foreground modes of encountering colonial material centered on restoring the personhood denied to the subjects documented by these archives. These modes of encounter that decenter Western principles of heritage curation are usually not considered in the early stages of conceptualizing and devising digital archives, which prevents more nuanced and imaginative notions of access from taking form.

The digitization of these records occasioned many difficult conversations on how to reconcile the mandates of Western collecting institutions with the desires and needs of documented communities and their descendants. But these conversations mostly centred around institutional mandates and the need to find solutions for these mandates to remain in place in slightly more sensitive versions. It was challenging to foreground different conversations that went beyond this divide, especially conversations that critically question the very mandates of collecting institutions or that try to imagine other modes of engaging with colonial material outside those principles that continue to go unquestioned when not shrouded in benevolence.

In addition to the open access by default, a second idea advanced by the National Archives is that 'history must be told', which raises questions about 'the parameters of knowability and speakability' (Edwards 2016, p 63) of the past. Whose histories must be told? Which histories can in fact be told? What kind of knowledge can be gleaned from the epistemic instruments of colonial powers? How does one encounter archives about people who were not active producers of records, who were mostly recorded against their will, and 
how does one account for their lives through the accounts of others? In this sense, the records can be said to enable as much to impede access to the lives of documented subjects: while the records only provide indirect access to their lives, open access to the records can potentially foster new ways of 'being accessed' that expand the modes through which colonial governance accessed, exploited and claimed ownership over enslaved and colonized subjects. Here I extend the notion of 'being accessed' proposed by Stefano Harney and Irit Rogoff (2015), who conceptualize digital access as a new but often unnoticed mode of registration and subject formation. Such modes of registration are a constitutive part of today's digitally constituted existence, whereby any subject accessing information in the digital realm is in fact being accessed by those very digital systems (Zuboff 2019). Yet the racialization processes that underpin the archives of colonialism render documented subjects particularly vulnerable to digital modes of access (Browne 2015). As Tonia Sutherland (2017, p 37) forcefully argues, the digital sphere is structured by race in ways that render black and brown bodies as records, all too often with retraumatizing effects: 'who controls the digital afterlives of those whose lives have been stolen? (As is so often the case, to the "victor" belongs the spoils)'. These concerns testify to the contested notion of access, particularly in its digital form, and to the need to problematize and enrich its meanings beyond the liberal desire to make information free.

Both issues - the provision of access, and the histories that must be told - are deeply imbricated, and represent political, ethical and epistemological questions that require holistic discussion. They also require an interdisciplinary dialogue that brings together archival practice with debates in the fields of Atlantic slavery and digital culture, particularly conversations in postcolonial and black digital humanities. While I do not intend to formulate definitive or normative solutions to the questions raised by this case, I hope in the following sections to offer a deeper understanding of these intersecting problematics, and of the various challenges and stakes raised by these materials once they acquire digital form.

\section{The politics of archival (non-)knowledge}

Huey Copeland and Krista Thompson (2011, p 2) have suggested that the archive structures the practice of colonialism as much as its historical forgetting. This has to do with the difficulty of reconstructing the histories of colonized subjects through the traces left in the archives of the ruling classes. This question has long been at the heart of debates about 
colonial archives in the field of Atlantic slavery - debates that raise different concerns from those within post-structural archive theories, as they shift the focus of analysis from the operations and dynamics of archival power towards the subjects documented by the archives of European colonialism. Central to these discussions has been the productive tension between the desire to recover those documented subjects from archives structured by violence and dispossession, and the impossibility of recovery when one is dealing with archives whose organization is envisioned and managed so as to obliterate the colonized.

In their introduction to the special issue of Social Text on 'the question of recovery', Helton et al. (2015) detail how the impulse towards recovery in twentieth-century slavery studies was bound up with struggles against legalized forms of black exclusion from public life. Since the exclusion of Africans from narratives of historical progress constituted one of the most injurious manifestations of racism, early writers in the field of Black studies were deeply committed to recovering and demonstrating the prominent historical roles of African people. This commitment was reinvigorated during the civil rights and Black Power eras in the US, particularly in the face of Jim Crow restrictions on black scholars' access to archival records, in a period when records of slavery were often located in the South. With increased access to these archives, from the 1960s to the 1980s scholars explored the records of slaveholders for narratives of cultural agency and everyday forms of resistance. A rich body of work has grown out of this commitment to recovering black lives from the archives of slavery.

A different strand of thinking about archives of slavery rests on the premise that the archival technology itself precludes recovery, insofar as the archives were active agents in denying personhood to the enslaved. If, for Michel Foucault (2004, p 145), the archive represents 'first and foremost the law of what can be said, the system that governs the appearance of statements as unique events', within this context a more recent and productive concern has been with that which cannot be uttered by the archives of European colonialism. In the words of Simon Gikandi (2015), the Atlantic is a 'deep crypt' in which the voices and lives of the enslaved are imprisoned - and encrypted - underneath the archived history of capitalist modernity. While there is no lack of records concerning the European colonial enterprise - as the USVI records attest in their wealth of documentation of capitalist exploitation - it is important to note that the episteme of these archives enables certain knowledges at the expense of others. As Gikandi maintains, the aim of colonial 
record-keeping was not only to keep track of capitalist production, but also to naturalize and justify the system of forced labour and racial subjugation that was the engine of the colonial project:

Slave masters sought to assert their authority through relentless record keeping [...]. From Edward Long to Thomas Jefferson slave masters turned to writing as a will to power; record keeping, and the archiving gesture, was a form of violent control; the archive was an attestation to the authority of natural history, the key to the ideology of white power. Here, in the archive, the African could be reduced to the world of nature and the prehuman. And thus from logbooks and firsthand accounts of the slave trade to the major histories written by planters, the archive of the slavers established statements whose major role was to fix the African as an object, as chattel, as property, and indeed as the symbol of the barbarism that enabled white civilization and its modernist cravings (Gikandi 2015, p 92).

The breadth of records held in the archives pertaining to the USVI raises many of these issues: pay books, cargo books, auction books, lists of bonds, debt lists, loans for the acquisition of slaves, insurance policies, reckonings of slaves sold, compensation paid to slaveholders after emancipation - these records document the centrality of black labour, knowledge and skills to the development of capitalism, while precluding the recognition of such labourers as subjects, since they enter the archives as commodities.

Hortense Spillers (1987) makes an important distinction between flesh and body, a distinction that demarcates captive and free or liberated bodies, which is also in part produced through colonial archives. By abducting bodies from African communities, European colonial powers turned those bodies into flesh, 'that zero degree of social conceptualization' (Spillers 1987, p 67). Spillers (1987, p 67) refers to the processes through which subjects are turned into flesh ('lacerations, woundings, fissures, tears, scars, openings, ruptures, lesions, rendings, punctures') as 'hieroglyphics of the flesh'. The archival registration of enslaved bodies, and the decomposition of those bodies into different units of information, can also be conceived as one hieroglyphic moment that separates the captive from the free, a moment that registers and officializes the denial of human personhood. This demarcating registration, which distinguishes between those recognized as human and those to whom such definitions do not extend, is one of the conditions of possibility for Western liberalism. In discussions of 
access, it is therefore crucial to bear in mind that the knowledge produced by the colonial archive defined the enslaved as flesh, as property, and therefore as unqualified for access to the freedom that constituted the basis of white legal subjecthood. In addition, the enslaved were denied access to the archival technology itself, insofar as reading and writing were punishable acts. Colonial archives are characterized by this contradiction: while the enslaved are denied access to the archives as producers of knowledge, and denied access to freedom through the archives that produce them as property, they are at the same time central to the archive as producers of economic value (Aljoe et al. 2015, p 260), and as the bodies against which liberal subjecthood is imagined and recognized.

This contradiction at the heart of colonial archives shows that the notion of access is far from neutral. The history of the concept is deeply embedded in archival epistemes and the subject positions they both enable and disable. The privilege to grant access, one could therefore argue, is historically premised on a privileged subjecthood derived from the archives of colonial modernity. To borrow Denise Ferreira da Silva's (2009) terms, the archive could be conceptualized as a 'tool of raciality'. It is also the archive (among other processes and instruments) that creates the universal subject position whose 'right to access' or 'right to information' is recognized. Yet this 'right to access' is conceived and granted at the expense of the racialized and gendered subjects that become accessed and newly available for inspection, legibility and consumption as commodities.

\section{Colonial archives and data bodies}

Such archival epistemes continue not only to bear on understandings of custody and treatment of archival records once they acquire digital form, but also to inform conceptions of data. As scholars such as Simone Browne (2015), Jessica Marie Johnson (2018) and Jacqueline Wernimont (2019) have pointed out, the notion of data is deeply embedded in colonial histories of quantification that have a defining moment in the accounting and marking of enslaved bodies. If left unaddressed, the violence of these archival processes can 'reproduce themselves in digital architecture' (Johnson 2018, p 58). This can happen when digital archives mirror the organization of information adopted by slave traders and colonial officers. Johnson (2018, p 59) mentions that databases, for instance, often reinscribe enslaved Africans' biometrics by carrying 'the racial nomenclature of the time period (négre, moreno, quadroon) into the present and encode skin color, hair texture, height, weight, age, and 
gender in new digital forms, replicating the surveilling actions of slave owners and slave traders'. The reinscription of colonial modes of organizing knowledge into the database is often complemented and amplified by tools and features that offer users new modes of 'mining' the archives - for instance, the zooming lens or the thumbnail image - which can result in modes of access that further commodify and abstract already abstracted bodies.

Many digitization projects foster a 'drive for data', since they are often accompanied by data sprints and other initiatives where people are encouraged to 'mine' these archives. This can lead to a 'second order of violence' (Hartman 2008) whereby the bodies already numbered in the archives are requantified, thus becoming a new form of raw material from which new values can be extracted. Such values emerge in the form of 'bigger insights', given the volume and scaling enabled by digital material and computational technologies. The logic of 'the more data the better' is often mobilized to demonstrate the massive scale of the colonial enterprise, so often minimized in discourses of colonial innocence. The promise of big data can thus be alluring to counter the marginal status of colonialism in national memories, as the sheer volume of the numbers can carry the potential to convey the actual scale of the colonial project through quantification. But this logic of quantification - itself embedded in the archives - can stand in the way of centring the experiences of the communities who lived under colonialism and slavery. Inheriting quantified data that was already instrumental in the dehumanization of subjects, such computational methods often run the risk of accentuating the 'violence of abstraction' (Hartman 2008) by datafied means. Bodies once commodified by the archives return as raw material and currency in a sort of digital afterlife (Sutherland, 2017). At the same time, the non-quantifiable, unregistered and uncollected dimensions of the experience of those under slavery and bondage continue to go unnoticed and unattended, rather than being brought to attention. How to adequately reconstruct the history of colonialism and slavery through abstraction? How can abstraction adequately convey, instead of reproducing, the trauma, pain, emotions and resistance of those who lived under slavery and bondage? How to restore personhood through data?

Computational initiatives such as data sprints with colonial material often lead to the sense that the knowledge generated through these methods fails to address or adequately reflect the lives hidden under the categories and numbers through which they entered the archives. As Johnson (2018, p 61) importantly cautions, 'data without an accompanying humanistic analysis - an exploration of the world of the enslaved from their own perspective 
- serve[s] to further obscure the social and political realities of black diasporic life under slavery'. This is not to discard digital material and computational methods altogether, but to emphasize that in order to move beyond violent abstraction and economies of innocence and privilege, the use of such technologies has to be accompanied and informed by a critical analysis attentive to the colonial histories in which these technologies are embedded, and directed towards redressing the lives quantified by those archives.

What this means is that the creation of digital archives, as Roopika Risam (2018, p 58) suggests, 'is not simply a matter of transcribing and digitizing texts, but of producing new knowledge as well'. For this to happen, digital archives must acknowledge and question, rather than obscure, the colonial history of quantification and datafication; interrogate and disassemble, rather than repeat, the inherited structure of colonial archives; and recognize, rather than requantify, the human lives turned into property through the archives of slavery and colonialism.

Moreover, the production of new knowledge through digital archives requires a critical expansion of what counts as knowledge. What kind of knowledge is the most adequate to make sense of colonial material? This entails creating the conditions and space for communities to add their knowledge to the sources; developing descriptive systems sensitive to archival silences and wary of racist classifications; and making room to articulate the affects and emotions surrounding archival records. These would be important steps towards enriching the meanings of knowing, as well as centring the experiences of the communities who engage with the sources (Dize 2019).

Examples of digital projects such as the Early Caribbean Digital Archive - an open-access collection of pre-twentieth-century Caribbean texts, maps and images housed at Northeastern University - open up promising avenues to pursue critical and thoughtful ways to encounter colonial materials. The Early Caribbean Digital Archive integrates an interrogation of the colonial logic of the archive into the architecture of the website itself: it rearranges the available information (through remixing and reassembling) in ways that permit the unearthing of histories and narratives otherwise silenced by the organizing structure of colonial archives, and it allows the archiving of new materials that complement and revise colonial knowledge (Aljoe et al. 2015). Another promising example is the recently launched 'Freedom on the Move', a database of fugitives from North American slavery that aims to compile 'runaway ads' and make them available for crowdsourcing. The project has opted to 
refer to the enslaved as 'self-liberating' people instead of 'runaway slaves' in order to reconceptualize their agency and challenge the power of classification, pointing towards a digital archival practice that strives to recognize and honour the humanity of those who lived under slavery and bondage.

What these examples suggest is that digitization and digital tools can be harnessed not only to uncover the violence contained in archival sources, but also to restore the personhood of those wounded by colonial experience. These examples thus gesture towards an archival ethics of care centred on subjects that have yet to be adequately redressed. Ultimately, the hope is that such practices can begin to pave the way for an affective encounter that moves beyond economies of guilt and innocence, towards an actual acknowledgement of people's injuries and demands for transgenerational accountability.

\section{Towards a postcolonial ethics of care}

Recent calls within and outside the field of archival science have begun to foreground the need for a feminist ethics of care within archival practice, particularly when dealing with archives of colonialism, slavery and other violent histories (Mattson 2016; Moore 2012; Rowell and Cooksey 2019). Increasingly, digitization projects raise the question of how to deal with the pernicious effects of open access to contested and hateful records. In response to these concerns, scholars and archivists have been advocating a shift from open-access and liberal transparency ideals towards a practice of care centred on acknowledging, honouring and redressing (not only legally) record subjects and communities of descendants. In their article "From human rights to feminist ethics: radical empathy in the archives", Michelle Caswell and Marika Cifor (2016) propose a shift in the theoretical model archivists and archival studies scholars use to address social justice concerns - from a model based on legalistic understandings of individual rights, to one based on a feminist ethics of care. Within such an approach, they propose, 'archivists are seen as caregivers, bound to records creators, subjects, users, and communities through a web of mutual affective responsibility' (Caswell and Cifor 2016, p 24). They outline different kinds of responsibility worth bearing in mind when we analyse the case of the USVI records. For instance, they suggest that archivists have 'ethical responsibilities' based on 'affective relationships' that transcend space and time, which include the subjects documented by the archives, as well as communities of descendants with legitimate claims to records: 
The archivist has an affective relationship to those about whom records are created, often unwittingly and unwillingly. Such stakeholders include Indigenous and colonial subjects counted, classified, studied, enslaved, traded as property and/or murdered. In dealing with such records - and virtually every archivist has dealt with such records a feminist approach guides the archivist to an affective responsibility to empathize with the subjects of the records and, in so doing, to consider their perspectives in making archival decisions. This is in contrast to the dominant Western mode of archival practice, in which archivists solely consider the legal rights of records creators, too often ignoring the record subject and the sometimes fuzzy line between creator and subject. In the feminist approach, the archivist cares about and for and with subjects (Caswell and Cifor 2016, p 36, emphasis added).

This 'affective orientation' towards the documented subjects - those for whom the records have enduring consequences - represents a radical shift in the archival encounter, premised as it is on ethical responsibility rather than liberal modes of access. Yet the notion of archivists as caregivers deserves further attention. In this final section, I would like to take up Caswell and Cifor's call for further conceptualizations of how feminist ethics may cause us to rethink archival thinking and practice. Building on their proposed affective reorientation and its commitment to social justice, I will point to some tensions between a feminist ethics of care and postcolonial critiques of power. With these reflections, my aim is to draw attention to the colonial underpinnings of care so that the feminist ethics of care being called forth remains attentive to, and committed to redress, unequal power structures that continue to impose neglect and dispossession. Ultimately, by unpacking these tensions, I wish to emphasize the anti-racist and anti-colonial possibilities that a feminist ethics of care may help to foster.

A photograph from the colonial archives of the USVI offers an eloquent example through which to discuss these tensions. Throughout the centennial commemorations in Denmark, a daguerreotype portraying a white Danish girl, Louisa Bauditz, and her black wet nurse, Charlotte Hodge, acquired prominent visibility. The portrait was chosen to illustrate the exhibition 'Blind spots: images of the Danish West Indies colony' at the Royal Danish Library, therefore appearing in many public places throughout Copenhagen. This large exhibition about the visual cultural history of the islands, as the title 'Blind spots' indicates, focused on problematizing the visual epistemology of the colonial enterprise and questioning 
the presumed neutrality with which visual records (such as photographs, maps and postcards) are often perceived, particularly by former colonial powers. This daguerreotype speaks volumes to the entanglement of care work and colonialism: a portrait of a black woman whose life is barely documented in the archives, whose image appears to us through the archives of the ruling classes, and whose labour and skills were vital in sustaining the colonial project. Yet, despite all the violence contained in the image, this gendered form of work often occluded the violence of colonialism, since the depiction of feminized and racialized care labour came across (to white audiences) as benign, ultimately contributing to overshadow the traumatic experience of black women who laboured under slavery and bondage. While such labour sustained the colonial structure, the maternal connotations of care work read into the image ended up decentering the experience of subjugation to centre the benevolence of Danish colonialism.

The readings of this image as a benevolent affective relationship between Charlotte Hodge and Louisa Bauditz, as well as benevolent speculations about the relationship between Charlotte Hodge and the family for whom she worked, are indicative of the troubled relationship between colonialism and care. As postcolonial feminists have noted, care discourse can sometimes function ideologically to justify or conceal relationships of power and domination. Moreover, care labour itself was a crucial sphere through which colonialist structures were maintained (Narayan 1995). Such benevolent readings of the image, in their attempt to capture the complex affects bonding colonizer and colonized, often ended up reproducing the private-public dichotomy that insulates the private sphere - where care happens - from the politics that structure the public sphere, which is thought to be unconnected to the personal and interpersonal dynamics of caregiving.

These readings often repeated the minimization of care labour performed by women of colour with which feminist ethics of care has been charged. As many black feminists have argued, black women's experience of care profoundly challenges the conceptualization of care by Western feminisms, even if these conceptualizations are critical of essentialized and gendered conceptions of care under capitalism and patriarchy. Often denied the possibility to care for their own families, black women read care not as an unpaid and devalued private activity in the home (as traditionally seen by Western feminism), but as labour that black and other racialized women have to perform outside the sphere of their own family where the needs of others take precedence over the needs of their own kin (Graham 2007; Hooks 1991). 
As Patricia Hill Collins (1995, p 125) has noted, this caring in the public sphere represented an extension of care work in the home, and was structured by social subordination that could often entail sexual harassment. As Nalinie Mooten (2015, p 14) also adds, domestic service linked these women to the perpetuation of the colonial labour system in an (informal) extension of institutionalized slavery (see also Graham 1991). Furthermore, this care labour was part of an unequal power relation between white and non-white women. As Cynthia Enloe (quoted in Mooten 2015, p 14) writes: 'the paternalistic relationship between the white mistress on a tea or sugar plantation and her local servants is frequently held up as an example of what the colonizing mission was all about'.

Projects of care, as feminist science and technology scholar Michelle Murphy (2015, p 725) argues, are often embedded in 'romantic temptations' of caregiving that 'disconnect acts that feel good from their geopolitical implications'. Mobilizations of care, she cautions, tend 'to avoid addressing the ongoing, painful, and extensive forces of racism or colonialism that do not disappear with good intentions or by constructing spaces where such forces are not keenly felt by privileged subjects' (Murphy 2015, p 720). In order to unravel this entanglement, Murphy (2015, p 722) proposes to 'unsettle care', not to foreclose the potential of feminist mobilizations of care, but to invite 'ways to situate affection, attention, attachment, intimacy, feelings, healing, and responsibility as non-innocent orientations circulating within larger formations'. Significantly, Murphy's 'unsettling' of care is indebted to work of scholars and activists who theorize decolonization in Canada and the US (Unsettling Minnesota 2009) as a project that also 'responsibilizes settlers to histories, entanglements, and complications that come from the historical and current structural violence of colonialism that unevenly distributes pain, trauma, and vulnerability as much as rewards, pleasure, and privilege' (Murphy 2015, p 722).

How do these critiques of care help us nuance an ethics of care in archival practice and engagements with colonial archives more broadly? Acknowledging the entanglement of care and colonialism can be a step towards a political understanding of care, that is, towards understanding the politics that shape acts of care. Rather than conceiving care as an exclusively positive affect immune to power differentials, such critiques point to how care already circulates within 'non-innocent histories' (Murphy 2015), given the centrality of care to operations of colonialism, empire and capital (Narayan 1995; Ticktin 2011). This can help 
us align acts of archival care, and reparative modes of engaging with archival material, with more explicit commitments to racial and social justice.

My point, then, is not to discredit ethics of care for its entanglement with colonial and non-innocent histories, but rather to harness this entanglement to reorient ethics of care more firmly towards the identification and contestation of colonial legacies that continue to produce harm and neglect (as well as privilege and rewards) in the present. Thinking about care in the colonial context highlights the instrumental political uses to which models of care can lend themselves in contexts marked by ongoing neocolonial relations, namely in justifying and naturalizing relationships of power and domination. These considerations can help us nuance the notion of archivists as caregivers by acknowledging the colonial underpinnings of care, which is often translated into paternalistic understandings of archival custody. This acknowledgement is crucial for recognizing the asymmetry and hierarchies that structure caregiving practices. As Nalinie Mooten (2015, p 8) cautions: 'despite the best intentions, the caregiver is always in the position to dictate the ways in which care is given; more so, care is frequently defined as a heart-giving, selfless act' that leaves 'little room for care recipients to voice the ways in which they want to receive care'. These lessons can prompt us to ask different questions about care within archival engagements, especially in conditions of digital reproduction: who decides who cares, and what is deserving of care? Who defines these contested terms? Can care restore personhood? Can care be used to decentre colonial epistemologies and ontologies? And can care be harnessed for a consequent acknowledgement of historical injustices?

Coming back to my initial discussion of Danish colonial innocence, a postcolonial ethics of care may be better equipped to unearth and challenge the non-innocent histories buried in colonial archives and perpetuated in subsequent historical narratives and affective economies of innocence. This is not to say that asymmetrical relationships can be escaped through care, or that care can dismantle privilege; but through the prism of postcolonial critiques, care can move beyond an act of feeling good or doing good to become more committed to a profound transformation of power relations in the long term. What this says about the archival encounter is that social relations shaped by coloniality cannot be bracketed out by that encounter. Rather, the archival encounter needs to be rethought as a site where past and ongoing coloniality can be meaningfully acknowledged and confronted. 


\section{Concluding thoughts: an archival imagination for digital times}

The digitization of the colonial archives of the US Virgin Islands has pointedly shown that digitization is never a merely technical process, shaped as it is by national and racial imaginaries, power differentials, affective economies of guilt and innocence and colonial legacies that continue to unevenly distribute both harm and privilege. While the case of the USVI records has motivated an important expansion of the notions of custody and provenance within archival science (Bastian 2003), I have argued that more work needs to be done to question, challenge and expand the notions of access at the heart of postcustodial thinking, in particular when dealing with digital colonial archives. Digitization is not neutral, nor is it the only way to think about access. A persistent consequence of colonialism is people's lack of control over how relevant information and cultural knowledge about their communities is used and interpreted. It is the power of the knowledge contained in the archive that needs to be returned. Access thus needs to be reconsidered in ways that confront and challenge these colonial legacies. This entails considering further obstacles to access that digitization alone does not resolve and may in fact entrench: language barriers, unequal digital infrastructures, insufficient or inadequate metadata, radically incommensurate experiences of colonialism that dictate radically different ways of engaging with archival material. Epistemologically, it also entails considering the racializing processes that shape the notion of access and notions of data. These racializing processes operate in and through colonial archives and need to be recognized when moving colonial archives to the digital sphere.

The digital afterlife of the colonial archive is another aspect that needs to be considered when moving colonial materials to digital spaces. Once admitted to the digital sphere, colonial material, in particular visual material, will be subjected to processes of posthuman curation through algorithms that will dictate new contexts for their reception. Colonial images will be further extracted from their context of production and storage with effects that need to be further investigated. This is particularly troublesome when these images represent violated subjects already photographed against their will. Through algorithmic processes, these images will further escape the interpretive control of the communities from which they emanate and potentially amplify colonial economies of seeing. In a reading of Louis Agassiz's photographs, Saidiya Hartman ponders on how these images 'train us to look and determine how we see and what we see', given their wide and continued 
circulation (Hartman, 2011, p. 522). Hartman's concerns acquire new and daunting contours, as images today are no longer seen by humans alone, but by machines as well. Algorithms are also 'trained' to look by visual material amassed on digital spaces. Racist modes of seeing are already being replicated by algorithms and their multiple and dangerous applications (Agostinho, 2018; Samudzi, 2019). A new archival ethics needs to reckon with this digital afterlife of the colonial archive.

These perils further substantiate the point that digitization is not only a matter of transcribing and digitizing materials, but also of producing new knowledge (Risam 2018). In fact, given these perils, perhaps digitization should be all about creating the conditions for new knowledge that pushes against the limits of colonial archives. Producing new knowledge is also a way to confront the politics of our lack of knowledge (Lowe 2015). Because colonial archives subsume histories of violence and resistance under narratives of capitalist accounting and state reason, these archives need to be enriched with their surplus, with what exceeds their epistemic framework. This often requires an imaginative exercise that complements and enriches historical accounts. In response to the apparent silence of enslaved voices in the archives, Saidiya Hartman notably called for a 'critical fabulation', an approach which attempts 'to jeopardize the status of the event, to displace the received or authorized account, and to imagine what might have happened or might have been said or might have been done [ . . .] The intent of this practice is not to give voice to the slave, but rather to imagine what cannot be verified, a realm of experience which is situated between two zones of death - social and corporeal death — and to reckon with the precarious lives which are visible only in the moment of their disappearance' (Hartman 2008, p. 11-12). In her latest book, Hartman pushes this imaginative exercise further to compel us to imagine the surplus that the archives have constructed as unimaginable. She urges us to 'press at the limits of the case file and the document' (Hartman 2019, p. 2) to attend to what has remained unthought due to the knowledge we received from these archives. Attending to the unthought is also part of undoing the colonial legacies that continue to structure our encounters with colonial archives. Perhaps the most powerful element of an archival imagination for digital times lies herein - in making room for the unthought to be articulated and heard.

\section{Acknowledgements}


This article is indebted to multiple and ongoing conversations about the legacies of colonialism in Denmark and the US Virgin Islands. I particularly thank Katrine Dirckinck-Holmfeld, La Vaughn Belle, Tami Navarro and the Uncertain Archives collective for inspiring collaborations and support. I would also like to express my gratitude to the editors of this special issue for their incredible intellectual input. Their generous and insightful comments have profoundly shaped the present version of this article. All remaining flaws can be attributed only to me.

The article is based on research funded by the Danish Council for Independent Research and the Novo Nordisk Foundation.

\section{References}

Agostinho D (2018) Chroma key dreams: Algorithmic visibility, fleshy images and scenes of recognition, Philosophy of Photography 9(2), 131-156

Araújo AL (2017). Reparations for slavery and the slave trade: A transnational and comparative history. London: Bloomsbury

Aljoe NN, Dillon EM, Doyle B, Hopwood E (2015) Obeah and the early Caribbean digital archive. Atlantic Studies 12(2):258-266

Andersen AN (2014) Islands of regret. Restitution, connected memories and the politics of history in Denmark and the US Virgin Islands. PhD Thesis, Aarhus University

Andersen AN (2018) The reparations movement in the US Virgin Islands. J Afr Am Hist 103(1-2):104-132

Bastian JA (1999) Defining custody. Archival custody and its impact on the relationship between communities and historical records in the information age. A case study of the US Virgin Islands. PhD Thesis, University of Pittsburgh

Bastian JA (2001) A question of custody. The colonial archives of the US Virgin Islands. Am Arch 64(1):96-114

Bastian JA (2002) Taking custody, giving access. A postcustodial role for a new century. Archivaria 53:76-93

Bastian JA (2003) Owning memory. How a Caribbean community lost its archives and found its history. Libraries Unlimited, Westport

Belle LV (2018) I am Queen Mary. Artist talk and panel debate. National Gallery of Denmark, Copenhagen, 1 Apr.

Browne S (2015) Black matters. On the surveillance of blackness. Duke University Press, Durham

Caswell ML (2016) 'The archive' is not an archives. On acknowledging the intellectual contributions of archival studies. Reconstruction: studies in contemporary culture 16(1)

Caswell ML, Cifor M (2016) From human rights to feminist ethics. Radical empathy in the archives. Archivaria 81:23-43

Caswell ML, Punzalan R, Sangwand TK (2017) Critical archival studies. An introduction. Journal of Critical Library and Information Studies 1(2) doi:10.24242/jclis.v1i2.50

Collins, PH (1995) Black women and motherhood. In: Held J (ed) Justice and care. Essential readings in feminist ethics. Westview Press, Boulder, 117-135

Copeland H, Thompson K (2011) Perpetual returns. New World slavery and the matter of the visual. Representations 113:1-15 
Danbolt M, Wilson MK (2018) A monumental challenge to Danish history. Kunstkritik, 26 Apr. http://www.kunstkritikk.no/kommentar/a-monumental-challenge-to-danish-history/ Accessed 25 Aug. 2018

Dirckinck-Holmfeld, K, Agostinho D, Søilen KLG (2019) Archives that matter. Digital infrastructures for sharing unshared histories. Nordic Journal of Information Studies and Cultural Communication 8(3)

Dize, N (2019) Feeling grief. On emotions in the archive of enslavement. Nursing Clio, 22 Jan. https://nursingclio.org/2019/01/22/feeling-grief-on-emotions-in-the-archive-of-enslavement/ Accessed 17 Apr 2019

Edwards E (2016) The colonial archival imaginaire at home. Social Anthropology/Anthropologie Sociale 24(1):52-66

Foucault M (2004) The archaeology of knowledge. Routledge, London

Gikandi S (2015) Rethinking the archive of enslavement. Early Am Lit 50(1):81-102

Graham H (1991) The concept of caring in feminist research. Sociology 25(1):61-78

Graham M (2007) The ethics of care, black women and the social professions. Implications of a new analysis. Ethics and Social Welfare 1(2):194-206 doi:10.1080/17496530701450372

Harney S, Rogoff I (2015) How not to be accessed thusly. Seminar at Bergen Assembly. http://bergenassembly.no/event/seminar-4-stefano-harney-and-irit-rogoff/ Accessed 1 Sep. 2018

Hartman S (2008) Lose your mother. A journey along the Atlantic slave route. Farrar, Straus and Giroux, New York

Hartman S (2011) Review of Delia's tears: race, science, and photography in nineteenth-century America, Journal of American History, 98(2): 520-522

Hartman S (2019) Wayward lives, beautiful experiments. Intimate Histories of Social Upheaval. New York:W. W. Norton \& Company

Helton L, Leroy J, Mishler MA, Seeley S, Sweeney S (2015) The question of recovery. An introduction. Soc Text 33(4) doi:10.1215/01642472-3315766

Hooks B (1991) Yearning. Race, gender, and cultural politics. Turnaround, London

Ipsen P (2014) Daughters of the trade. Atlantic slavers and interracial marriage on the Gold Coast. University of Pennsylvania Press, Philadelphia

Jensen L (2018) Postcolonial Denmark. Nation narration in a crisis ridden Europe. Routledge, London

Johnson JM (2018) Markup bodies. Black [life] studies and slavery [death] studies at the digital crossroads. Soc Text 36(4):57-79

Kelleher C (2017) Archives without archives. (Re)locating and (re)defining the archive through post-custodial praxis. Journal of Critical Library and Information Studies 1(2) doi:10.24242/jclis.v1i2.29

Körber LA (2018) Gold Coast (2015) and Danish economies of colonial guilt. Journal of Aesthetics and Culture 10(2):25-37

Lowe L (2015) The intimacies of four continents. Duke University Press, Durham

Mattson R (2016) Can we center an ethics of care in audiovisual archival practice? XFR Collective, 2 Dec.

https://xfrcollective.wordpress.com/2016/12/02/can-we-center-an-ethic-of-care-in-audiovisua 1-archival-practice/ Accessed 18 Apr 2019

McBride DA (2011) Impossible witnesses. Truth, abolitionism and slave testimony. New York University Press, New York 
Moore N (2012) The politics and ethics of naming. Questioning anonymisation in (archival) research. International Journal of Social Research Methodology 15(4):331-340 doi: $10.1080 / 13645579.2012 .688330$

Mooten N (2015) Toward a postcolonial ethics of care. https://ethicsofcare.org/wp-content/uploads/2016/12/Toward_a_Postcolonial_Ethics_of_Care .pdf Accessed 10 Apr. 2019

Morgan JL (2004) Laboring women. Reproduction and gender in New World slavery. University of Pennsylvania Press, Philadelphia

Murphy M (2015) Unsettling care. Troubling transnational itineraries of care in feminist health practices. Social Studies of Science 45(5):717-737

Narayan U (1995) Colonialism and its others. Considerations on rights and care discourses. Hypatia 10(2): 133-140

Navarro T (2017) From Danish west indies to American poorhouse. Small axe salon 26.

Odumosu T (2017) Loving in the colonial archive. A short mediation in three parts. Marronage $1: 22-25$

Odumosu T (2019) The crying baby. On colonial archives, digitisation, and ethics of care in the cultural commons. Paper presented at Malmö University, 27 Feb.

Rigsarkivet (n.d.) The Danish West-Indies. Sources of history. https://www.virgin-islands-history.org/en/about/hvorfor-dette-website/ Accessed 12 Apr. 2019

Risam R (2018) New digital worlds. Postcolonial digital humanities in theory, praxis, and pedagogy. Northwestern University Press, Evanston

Rowell CJ, Cooksey T (2019) Archive of hate. Ethics of care in the preservation of ugly histories. Lady Science, 9 Jan.

https://www.ladyscience.com/blog/archive-of-hate-ethics-of-care-in-the-preservation-of-ugly -histories Accessed 25 Feb 2019

Samudzi Z (2019) Bots are terrible at recognizing Black faces. Let's keep it that way. Daily Beast, 2 Febr 2019. Accessed 17 Apr 2019

Silva DF (2001) Towards a critique of the socio-logos of justice. The analytics of raciality and the production of universality. Social Identities 7(3):421-454

Silva DF (2009) No-bodies. Law, raciality and violence. Griffith Law Review 18(2):212-236

Simonsen G (2017) Slave stories. Law, representation, and gender in the Danish West Indies. Aarhus University Press, Aarhus

Spillers H (1987) Mama's baby, papa's maybe. An American grammar book. Diacritics 17(2):64-81

Stoler AL (2002) Colonial archives and the arts of governance. Archival Science 2:87-109

Sutherland T (2017) Making a killing. On race, ritual, and (re)membering in digital culture. Preservation, Digital Technology and Culture 46(1):32-40

Taylor D (2003) The archive and the repertoire. Performing cultural memory in the Americas. Duke University Press, Durham

Ticktin MI (2011) Casualties of care. Immigration and the politics of humanitarianism in France. University of California Press, Oakland

Unsettling Minnesota (2009) Unsettling ourselves. Reflections and resources for deconstructing colonial mentality. Unsettling Minnesota, Minneapolis http://unsettlingminnesota.files.wordpress.com/2009/11/um_sourcebook_jan10_revision.pdf Accessed 17 Apr 2019

Wekker G (2016) White Innocence. Paradoxes of colonialism and race. Durham: Duke University Press

Wernimont J (2019) Numbered lives. Life and death in quantum media. MIT Press, Cambridge 
Zuboff S (2019) The age of surveillance capitalism. The fight for a human future at the new frontier of power. Public Affairs, New York 